Jurnal DinamikA

Volume 2 No. 2 (2021)

E-ISSN: 2723-1410

Website: https://jurnal.iainsalatiga.ac.id/index.php/dinamika/index

\title{
Vowel Pronunciation of English Words By Filipino Speakers in "Everglow" Short Movie
}

\author{
Ingielly Melienia \\ ingielly.melienia@gmail.com
}

\begin{abstract}
Language is a way of communication with other people. People can make conversation through a set of words that become a sentence. There is one language that uses as the International language to communicate with other people who come from other countries in this world. Thus, English is used as an intermediate language for communication. One of nations, that use English to communicate, is the Philippines. The research found some phenomena that exist when Filipino speakers speak English. There were two objectives to be analyzed in this study: to find out the English words that the vowel is changing from English vowel into Tagalog vowel and identify the phonological process of Filipino speakers' pronunciation in the vowel change. The phonological approach is used to solve the problem formulation of the research. The research analyzed a short movie entitled "Everglow" from the Philippines and analyzed the vowel changes in Filipino speakers' pronunciation. The analysis showed that there were 11 English vowels changes in Filipino speakers' pronunciation. Furthermore, three phonological processes were found in the vowel change, such as vowel lengthening, vowel raising, and vowel insertion. However, the most phonological process that was usually found in the vowel changes was the vowel lengthening.
\end{abstract}

\section{Keywords: vowel change, Filipino, phonology.}

\section{Introduction}

"Language is the institution whereby humans communicate and interact with each other by means of habitually-used oral-auditory symbols" (Halle, 1968, p.158). It means that language functions are to interact, communicate, share knowledge, skills, or information. There are many languages in this world, such as English as the 


\section{Jurnal DinamikA}

Volume 2 No. 2 (2021)

E-ISSN: 2723-1410

Website: https://jurnal.iainsalatiga.ac.id/index.php/dinamika/index

lingua franca. According to Samarin, lingua franca is usually taken to mean "any lingual medium of communication between people of different mother tongues, for whom it is a second language (1987, p.371). It will help people to communicate with other people who come from other countries.

Some people might find it very difficult to study English, which is not their mother tongue. An example is shown by some people from Thailand and Filipino who try to achieve foreign languages' pronunciation like a native or near-native accent. In contrast, they do not pronounce it correctly because of their mother tongue. It is one of the problems for every people who are not as a native speaker in non-English countries. This phenomenon occurs due to their language can not produce sounds like English native speakers. The statement is how a sound is produced variation from language to language.

As mentioned above, that some languages are used in other languages. As a result of this, the non-native speakers pronounce its word incorrectly. It could be the consonant and vowel change, consonant or vowel deletion, and a consonant or vowel insertion. It means the phonological process happened. Phonological systems are not made up of isolated and unrelated phonological rules; there are usually significant interactions between phonological processes (Odden, 2005, p.100). It means that the phonological process is used to see the different pronunciation between the standard of IPA and non-native speakers' pronunciation. In this research, the researcher will analyze the vowel pronunciation of English words to other languages. One of the other languages is Filipinos. Filipinos speak some English words, but they have different ways of pronouncing them.

In this respect, the researcher has two objectives to undergo this research. The first objective is to categorize the words in the dialogue of "Everglow," a short movie in which the vowels change from English to Tagalog. It can be seen by how Filipino speakers pronounce English words. The second objective is to identify Filipino speakers' phonological process, which happens in the vowel change. The researcher wants to present that people have a different way of pronunciations. The 


\section{Jurnal DinamikA}

Volume 2 No. 2 (2021)

E-ISSN: 2723-1410

Website: https://jurnal.iainsalatiga.ac.id/index.php/dinamika/index

identification of the phonological process helps the native speaker to understand what the non-native speaker said.

Several previous studies relate to this study. The first study is conducted by Hermastuti \& Isti'anah (2018). It analyzed the change of consonants by Korean singers. It showed the phonological patterns found in the shift of consonants. For analysing the research, the researchers used a phonological approach to show the phonological process happened. The next study is conducted by Purba, Bangun, Pramana, Sinaga, and Tarigan (2019). The researchers analyzed the correct and incorrect vowel pronunciation by the eighth grade of SMP Swasta Puteri Sion. It focuses on vowel sounds that are produced by the students. It found the reasons why many students have the wrong pronunciation, especially in the vowel. On the other hand, this study analyzes the change of vowel pronunciation of Filipino speakers' English words. The third study examined the errors of vowel pronunciation that are produced by Informatics students. It is made by Frijuniarsi (2018). The research aimed to find out the vowel errors that pronounced by second-semester students of Informatics. Besides, it also finds out the reasons why the students pronounced incorrectly. For realizing the objectives, the researcher used the phonological approach as its foundation. In this study, the researcher will explain the phonological processes in the change of vowel pronunciation. It uses the same approach with the previous studies, which is a Phonological approach. The earlier studies mentioned that the research develops the theory of phonological processes that happened in vowel pronunciation. The researcher's statement is also how a vowel sound of English words has variation produced from English to Tagalog.

This study aims to determine the vowel pronunciation of English words changed by Filipino speakers in the "Everglow" short movie. Through the vowel pronunciation change, the phonological process in the short movie can be revealed.

\section{Methodology}

The object of the study is a short movie that is taken from one of the Youtube channels. It is from the COF Studios Youtube channel, which has the short movie title is "Everglow." It is a Filipino Drama that tells about the relationship of the best 


\section{Jurnal DinamikA}

Volume 2 No. 2 (2021)

E-ISSN: $2723-1410$

Website: https://jurnal.iainsalatiga.ac.id/index.php/dinamika/index

friends who will separate because they must achieve their future by themselves. From that short movie, the researcher found some English words in the actors and actresses' conversation. This study analyzes the change of vowel pronunciation of English words produced by the actors and actresses. It means a phonological approach is applied as its foundation. This approach deals with the sound of the language. According to McMohan, phonology is the sound patterns of particular languages (2002, p.2). It allowed the researcher to solve the problems formulated in the part of problem formulation. Based on the phonological features, the phonological approach will help find the words' phonological process. This approach is used in determining the phonological reasons causing the change of vowel pronunciation in the conversation of the "Everglow" short movie by the actors and actresses.

In the study, the researcher illustrated the pronunciation changes of English words vowel from English to Tagalog. It shows how the Filipinos pronounce the English words. The researcher listened to the short movie for the second time to focus on the English words. The researcher will pay attention to how the casts pronounce the English words. It shows that the researcher is using auditory observation. The researcher collected the data with the table, such as English words, English Pronunciation, Tagalog Pronunciation, The Change of Vowel, and the Phonological Processes. The English words were found when the actors and actresses speak in the "Everglow" short movie's conversation. For English Pronunciation, it is the phonetic of that word, whereas Tagalog Pronunciation shows how the casts pronounce the English word according to what the researcher listens to and the Tagalog phonology. The researcher applied the notation of phonological rules.

\section{Findings and Discussion}

The researcher found seven vowels that have different pronunciation from the standard of English phonetics based on the Oxford dictionary pronounced by Filipino speakers in the "Everglow" short movie in their conversation. Besides, four 
Jurnal DinamikA

Volume 2 No. 2 (2021)

E-ISSN: $2723-1410$

Website: https://jurnal.iainsalatiga.ac.id/index.php/dinamika/index

vowels that are inserted in some words. It is because of the production of Filipino speakers. Therefore, three phonological processes that happen.

\section{Vowel Lengthening}

There are some vowel changes that occur during the process of vowel lengthening. It is found in some the English words in their conversation. According to Weisler and Milekic, vowel lengthening is the process lengthening of vowels that are located before voiced consonants (2000, p. 51). However, the researcher found some vowels affected by the vowel lengthening, but the vowels are not located before voiced consonants. It can be the effect of their mother tongue or the theory is because of their language's phonology. The researcher will give a table to mention the vowels affected by the process of vowel lengthening.

Table 1. Vowels that are affected by vowel lengthening

\begin{tabular}{|c|c|c|c|c|}
\hline No. & $\begin{array}{c}\text { Intended } \\
\text { Pronunciation }\end{array}$ & $\begin{array}{c}\text { Filipino's } \\
\text { Pronunciation }\end{array}$ & $\begin{array}{c}\text { Features of } \\
\text { Intended } \\
\text { Pronunciation }\end{array}$ & $\begin{array}{c}\text { Features of } \\
\text { Filipino's } \\
\text { Pronunciation }\end{array}$ \\
\hline 1. & [æ] & [a] & $\begin{array}{c}\text { +low, +low, - } \\
\text { tense }\end{array}$ & $\begin{array}{c}\text { +low, +open, } \\
+ \text { tense }\end{array}$ \\
\hline 2. & {$[\mathrm{I}]$} & [i] & $\begin{array}{c}\text { +high, }+ \text { close, - } \\
\text { tense }\end{array}$ & $\begin{array}{l}\text { +high, +close, } \\
+ \text { tense }\end{array}$ \\
\hline 3. & [0] & [o] & $\begin{array}{c}+ \text { mid, }+ \text { open, } \\
\text { tense }\end{array}$ & $\begin{array}{c}+ \text { mid, }+ \text { close } \\
+ \text { tense }\end{array}$ \\
\hline 4. & [a] & [o] & $\begin{array}{c}\text { +low, +open, - } \\
\text { tense }\end{array}$ & $\begin{array}{c}+ \text { mid, }+ \text { close } \\
+ \text { tense }\end{array}$ \\
\hline 5. & [U] & {$[\mathrm{u}]$} & $\begin{array}{c}\text { +high, }+ \text { close, - } \\
\text { tense }\end{array}$ & $\begin{array}{c}\text { +high, +close, } \\
+ \text { tense }\end{array}$ \\
\hline 6. & [a] & [a] & $\begin{array}{c}\text { +low, +open, - } \\
\text { tense }\end{array}$ & $\begin{array}{c}\text { +low, +open, } \\
+ \text { tense }\end{array}$ \\
\hline
\end{tabular}


Jurnal DinamikA

Volume 2 No. 2 (2021)

E-ISSN: $2723-1410$

Website: https://jurnal.iainsalatiga.ac.id/index.php/dinamika/index

Based on table 1, the researcher will explain the table the below.

a. Intended Pronunciation means the English vowel that is pronounced based on the Oxford dictionary.

b. Filipino's Pronunciation means the Tagalog vowel that is pronounced by Filipino speakers.

c. Features of Intended Pronunciation means the height, closeness, and tenseness of the English vowel.

d. Features of Filipino's Pronunciation means the height, closeness, and tenseness of the vowel Tagalog.

Table 1 shows that some vowels are different in the tenseness of the tongue. For example, it is revealed by [æ] is [-tense] and [a] is [+tense]. There are two tensenesses of the tongue, such as lax and tense. According to Hazen, "the tense and lax distinction largely replaced the long and short system of Old and Middle English” (2014, p. 52). It means that tense is the long articulation and lax is short articulation. The long articulation or tense is shown by the vowel [a], whereas the short articulation or lax is presented by the vowel [æ]. The word that experiences the vowel lengthening in this environment is "hang," that is derived from the verb "hang out."

Hang : /hæy/ $\rightarrow$ [hay].

It is the change of English pronunciation into how the Filipino speakers pronounced it. The phonotactic notation is shown below.

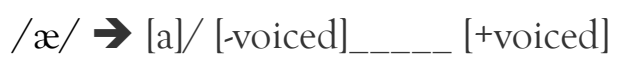

The change vowel æ into a occurs between the voiceless and voiced consonant. It is shown that the vowel change of $æ$ is because /æ/ lies on before the voiced consonant. 


\section{Jurnal DinamikA}

Volume 2 No. 2 (2021)

E-ISSN: $2723-1410$

Website: https://jurnal.iainsalatiga.ac.id/index.php/dinamika/index

Therefore, it changes from the short vowel into the long vowel. There are six words that are affected by vowel lengthening in this vowel change of /æ/ into [a].

Another example is shown by vowel [I] and [i] from two words. The vowel [I] is a lax vowel, which means it has short articulation. While the vowel [i] is a tense vowel, which means it has long articulation. From the lax vowel into the tense vowel, it is shown that the vowel lengthening occurred. Six words got affected by the vowel lengthening. Two of the words are "exam" and "interested." The word is provided to show vowel lengthening.

Exam : /Igzæm/ $\rightarrow$ igsim]

Interested : /IntrəstId/ $\rightarrow$ [interestid]

It is seen that /I/ is changing into [i]. It happened two times for the word "interested," the beginning and the end of the word. The front and end occur because of the consonant $/ \mathrm{n} /$ and / $\mathrm{d} /$, voiced consonants. While the word "exam" occurred before the voiced consonant of ' $\mathrm{g}$.' According to the theory, the change of a tense vowel to a lax vowel is called vowel lengthening. It is shown that the vowel /I/ affected by the vowel lengthening. The phonotactic notation explains how it can change.

$$
/ \mathrm{I} / \rightarrow[\mathrm{i}] /[-\ldots+[+ \text { voiced]. }
$$

The same phenomenon happens in the vowel $/ \mathrm{o} /$. The word that experiences the vowel lengthening is "board." It is the shift and the phonotactic notation of "board."

$$
\begin{aligned}
& \text { Board } \quad: / \text { bord } / \rightarrow \text { [borde] } \\
& / \mathrm{o} / \rightarrow[\mathrm{o}] / \text { _-_-_- }[+ \text { voiced }]
\end{aligned}
$$

It shows that the lax vowel $/ \mathrm{J} /$ changes to the tense vowel [o]. This phenomenon happens when the vowel $/ \mathrm{J} /$ is located before voiced consonant or consonant ' $r$.' 


\section{Jurnal DinamikA}

Volume 2 No. 2 (2021)

E-ISSN: 2723-1410

Website: https://jurnal.iainsalatiga.ac.id/index.php/dinamika/index

Therefore, the vowel lengthening happened. Another phonological process occurs in this word, but it will explain in the last discussion.

The next vowel is / $\mathrm{a} /$ that is affected by the vowel lengthening. The tense vowel $/ \mathrm{a} /$ changes into the tense vowel [o]. The phonotactic notation and the shift of that word will show why the vowel lengthening happened.

$$
\begin{aligned}
& \text { Conscious : } / \text { kanjəs } / \rightarrow \text { [konsus }] \\
& / \mathrm{a} / \rightarrow[\mathrm{o}] / \text { _-_-_-_ }[+ \text { voiced]. }
\end{aligned}
$$

The vowel lengthening happens to cause the vowel /a/ where lies on before voiced consonant. As analyzed above, the same phenomenon occurred in this vowel. Another phonological process that occurred in this word will explain in the second discussion.

The fifth analysing can be seen in the change of vowel /a/ into [a]. Two words that are affected by vowel lengthening. One of those words is "fast." There is an interesting phenomenon in this pronunciation. It will explain after the researcher showed the shift and the phonotactic notation of "fast" as follows:

$$
\begin{aligned}
& \text { Fast }: / \text { fast } / \rightarrow \text { [fast }] \\
& / \mathrm{a} / \rightarrow \text { [a] / _-_-__ [-voiced]. }
\end{aligned}
$$

From the phonotactic notation above, the change of vowel / $\mathrm{a} /$ happened before consonant 's', which means the voiceless consonant. As mentioned above, vowel lengthening is the vowel change process from lax into tense before a voiced consonant. However, it happens before a voiceless consonant. It can happen because of the environment of Tagalog.

Next analysing is the vowel $/ \mho /$, which has features as high position, close of the closeness, and lax articulation. It changes into tense articulation. It occurs in the word "out," derived from the verb "hang out." The intended pronunciation and the cast's pronunciation are shown in the below. 
Jurnal DinamikA

Volume 2 No. 2 (2021)

E-ISSN: 2723-1410

Website: https://jurnal.iainsalatiga.ac.id/index.php/dinamika/index

Out $\quad: /$ avt $/ \rightarrow$ aut $]$

The vowel lengthening has happened in the change of vowel / $\mho /$ into [u]. However, it is not because of the voiced consonant as we know from the theory, but it gets the environment from Tagalog phonology. Tagalog Phonology which focuses on the vowel, they do not have vowel / $\mho /$ there. According to the Schachter and Otanes, Tagalog has five vowels, such as /i, e, a, o, u/ $(1972$, p.6). It means that the change of vowel $/ \mathrm{v} /$ into $[\mathrm{u}]$ is because they got the environment from their mother tongue, Tagalog. The researcher gives the phonotactic notation below.

$/ \mho / \rightarrow[\mathrm{u}] /$ _-_-_-_ [-voiced].

The changing of $/ \mho /$ into $[u]$ also can be happened because of the theory mentioned above. It states that the vowel lengthening happens to cause the voiced consonant after the vowel. It is showed by the word "cum" which came from an adverb, "cum laude." The result pronunciation produced by Filipino speakers is presented the below.

Cum : $/ \mathrm{k} \mho \mathrm{m} / \rightarrow[\mathrm{kum}]$

It is affected by vowel lengthening. There is changing the vowel / $\mathrm{\mho} /$ becomes $[\mathrm{u}]$ before the voiced consonant. The voiced consonant is " $m$," which hits the vowel $/ \mho /$. The phonotactic notation as follows:

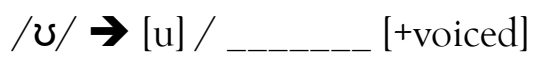

From the analysing of vowel change / $\mho /$ into $[\mathrm{u}]$, the vowel lengthening can happen because the environments of Tagalog phonology and the theory of English phonological process. 
Jurnal DinamikA

Volume 2 No. 2 (2021)

E-ISSN: $2723-1410$

Website: https://jurnal.iainsalatiga.ac.id/index.php/dinamika/index

\section{Vowel raising}

Besides, the vowel lengthening, the other phonological process is vowel raising. It happens because the mid vowels raise to be high vowels (Walker, 2011, p.160). It increases the extent of realization for [+high] in a word. In this part, there are two vowels that change from mid vowel to high vowel. It will be given in table 2 .

Table 2. Vowels that affected by vowel raising

\begin{tabular}{|c|c|c|c|c|}
\hline No. & $\begin{array}{c}\text { Intended } \\
\text { Pronunciation }\end{array}$ & $\begin{array}{c}\text { Filipino's } \\
\text { Pronunciation }\end{array}$ & $\begin{array}{c}\text { Features of } \\
\text { Intended } \\
\text { Pronunciation }\end{array}$ & $\begin{array}{c}\text { Features of } \\
\text { Filipino's } \\
\text { Pronunciation }\end{array}$ \\
\hline 1. & [ə] & [i] & $\begin{array}{c}\text {-high } \\
\text { +unround, } \\
\text { +tense }\end{array}$ & $\begin{array}{l}\text { +high, } \\
\text { +unround, } \\
\text { +tense }\end{array}$ \\
\hline 2. & [ə] & {$[\mathrm{u}]$} & $\begin{array}{l}\text {-high, } \\
\text { +unround, } \\
\text { +tense }\end{array}$ & $\begin{array}{l}\text { +high, - } \\
\text { unround, } \\
\text { +tense }\end{array}$ \\
\hline 3. & {$[\varepsilon]$} & [i] & $\begin{array}{c}\text {-high, } \\
\text { +unround, +lax }\end{array}$ & $\begin{array}{l}\text { +high, } \\
\text { +unround, } \\
\text { +tense }\end{array}$ \\
\hline
\end{tabular}

According to table 2, the change of vowel pronunciation happens because of the process of vowel raising. For instance, it occurs in a word, "possibility," which has English pronunciation as /pDsəbIləti/ and the result of Filipino speaker is [pasibiliti]. A vowel /ə/, which has a feature in the mid position of height, has changed into [i]. In comparison, the vowel [i] has a high place of height. According to the theory above, a mid vowel has raised into a high vowel; it is called a vowel raising.

Another example is the change of the vowel /ə/ into vowel [u]. The vowel shift is based on the vowel chart below. 


\section{Jurnal DinamikA}

Volume 2 No. 2 (2021)

E-ISSN: $2723-1410$

Website: https://jurnal.iainsalatiga.ac.id/index.php/dinamika/index

Chart 1. Vowel Chart (Odden, 2005, p.21)

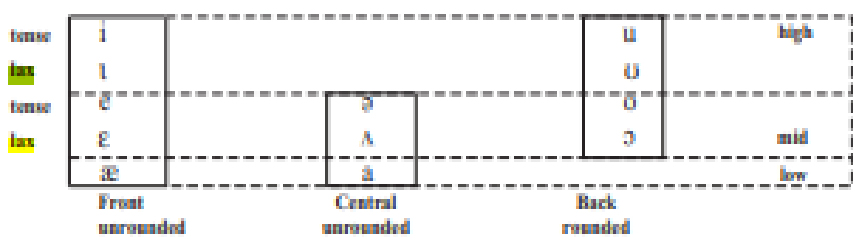

As the chart above shows, the vowel shift of $/ \partial /$ into $[\mathrm{u}]$ moves from mid-position, which is shown in the right column, to the high place. The word that got the effect of vowel raising in this vowel is "conscious." The English pronunciation is /kanfəs/ and [konsus] by the Filipino speaker. It shows that there is a vowel raising there.

The last analysing of this part is the change of vowel $/ \varepsilon /$. "Belt" is the only word that is affected by the vowel raising. It is derived from the phrase "below-thebelt." The Filipino speakers properly speak the word 'below' and 'the'. However, a word "belt" is spoken as [bilt] from the English pronunciation/belt/. It changes the vowel $/ \varepsilon /$ into [i], which is the vowel $/ \varepsilon /$ is in the mid position, and $[\mathrm{i}]$ is in the high position. Therefore, vowel raising happened.

\section{Insertion}

In the English phonology, phonological processes can happen. One of the rules of phonological processes is Insertion or Epenthesis. According to Fromkin et $a l$, epenthesis is the process of inserting a sound segment ( a consonant or a vowel) into a form (2003). However, the researcher focuses on the vowel insertion in some English words of the casts' conversation. The vowels insertion are shown as follows:

a. Vowel Insertion of /e/

King states that some vowels and consonants can be inserted either in the middle position or in the final position of the words (1973). For instance, six words got insertion from vowel/e/. Those words are shown as follows:

Class $\quad: /$ kla:s $\rightarrow$ [klase]

Board $\quad: /$ bo:rd $/ \rightarrow$ [borde]

Sure $\quad: / \int \mho r r / \rightarrow$ sure] 
Jurnal DinamikA

Volume 2 No. 2 (2021)

E-ISSN: $2723-1410$

Website: https://jurnal.iainsalatiga.ac.id/index.php/dinamika/index

\author{
Important : /Impo:rtnt/ $\rightarrow$ [importante] \\ Release $\quad: /$ rIliis/ $\rightarrow$ [rilise]
}

The words above show that the vowel insertion happened in the final position of the words. It occurred after the alveolar consonants such as /s, d, t/ and palatal consonant, $/ \mathrm{r} /$. The phonotactic notation will be given below.

$\varnothing \rightarrow \mathrm{e} /$ [+alveolar]_______-
$\varnothing \rightarrow \mathrm{e} /$ [+palatal]________\#

The one word that is different from others is "interested." It is because the vowel insertion happened between alveolar and palatal consonants. The shift and phonotactic notation of that word is shown as follows:

Interested : / IntrəstId/ $\rightarrow$ [interestid]

$\varnothing \rightarrow \mathrm{e} /[+ \text { alveolar }]_{-}-{ }_{-}[-[+$palatal $]$

b. Vowel Insertion of /o/

This phenomenon occurs in two words that are spoken by Filipino speakers. There are "graduation" and "passion." It is a vowel inserted between $/ \mathrm{s} /$ and $/ \mathrm{n} /$. It means the vowel insertion /o/ is located between the alveolar and palatal consonants. The vowel insertion /o/ of those words are shown below:

Graduation : /grædzueI]n/ $\rightarrow$ [graduefon]

Passion $\quad: / \mathrm{p}[\mathrm{n} / \rightarrow$ [pa $[\mathrm{on}]$

It showed that the vowel /o/ puts on the alveolar and palatal consonant. Therefore, vowel insertion happened. To display the phonological process, the researcher will give the phonotactic notation.

$\varnothing \rightarrow \mathrm{o} /[+ \text { alveolar }]_{-}-{ }_{-}[$[+palatal $]$

c. Vowel Insertion of /a/

Two words got inserted by vowel /a/. It is such as "important" and "problem." Those words have different when the vowel/a/ inserts in those words. 
Jurnal DinamikA

Volume 2 No. 2 (2021)

E-ISSN: $2723-1410$

Website: https://jurnal.iainsalatiga.ac.id/index.php/dinamika/index

The first insertion occurred before and after alveolar consonant. It is, for a word, "important."

Important : /Impכ:rtnt/ $\rightarrow$ [importante]

$\varnothing \rightarrow \mathrm{a} /$ [+alveolar]______[+alveolar]

The phonotactic notation above showed that the vowel/a/ inserted between two alveolar consonants. While a word, "problem" happened in the final position of the words or after a bilabial consonant. The word is shown below.

Problem : /pra:bləm/ $\rightarrow$ [prablema]

As mentioned above, the vowel can be inserted in the final position of the words. However, it also occurred after consonant, 'm'.

$\varnothing \rightarrow$ a / [+bilabial $]_{--}$

\section{d. Vowel Insertion of /i/}

There is one word in the conversation of the short movie by Filipino speakers. It is a word of "food," which happened in the words' final position or after alveolar consonant. The word is presented as follows :

Food

$: /$ fu:d $/ \rightarrow$ [fudi]

It shows that the insertion of vowel / $\mathrm{i} /$ happens after consonant " $\mathrm{d}$," is the alveolar consonant. Also, it reveals that the vowel insertion can happen in the final position of the words. For showing the phonological process, the phonotactic notation will be given below.

$\varnothing \rightarrow \mathrm{i} /$ [+alveolar $]$ $\#$

Based on the findings and discussion of vowel insertion above, the phonological process of insertion happens in the four English vowels such as /a, e, o, i/. It got affected by the alveolar, palatal, and bilabial consonants. It is also the position of the vowel, which is in the final of a word. The phonological process of insertion can happen because of the phonological rule of some languages. Therefore, this process can occur in some languages, especially Tagalog, in this research. 


\section{Jurnal DinamikA}

Volume 2 No. 2 (2021)

E-ISSN: 2723-1410

Website: https://jurnal.iainsalatiga.ac.id/index.php/dinamika/index

From the analysis and discussion above-mentioned, it is found that eleven vowels undergo a change in Filipino speakers' pronunciation. They are vowels [æ], [I], [0],

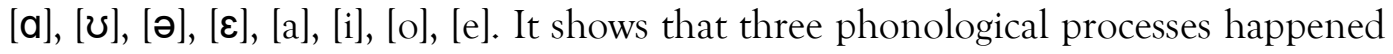
in the vowel change, such as vowel lengthening, vowel raising, and insertion when the Filipino actors and actresses speak English words. It can be concluded that Filipino speakers change the English vowel because of the Tagalog vowel which has five vowels such as /a, i, u, e, o/. It is also because the phonological processes happened in the vowel change. Therefore, Filipino speakers change the English vowel when they speak English. They can produce the correct English pronunciation if they understand and learn how to pronounce the other English vowels excluding Tagalog vowels.

\section{Conclusion}

The research object is taken from a short movie entitled "Everglow" by a Youtube channel that the casts are the original Filipino speakers. Therefore, the research's first objective is to find out the English words which have vowel changes by Filipino speakers. From the first objective, the research found that there are seven vowels that Tagalog vowels do not have in. Besides, based on the findings, four vowels reveal a different phonological process from the previous discussion.

In conclusion, based on the second objective of the research that is to analyze the phonological processes happened in the vowel changes, the research found the three phonological processes in the vowel changes produced by Filipino speakers pronunciation. There is the process of changing the lax vowel into a tense vowel or called the vowel lengthening, changing the mid vowel into a high vowel or called vowel raising, and the last is inserting a vowel or called as insertion. From the three phonological processes above, the most process that happened in changing vowels is when the vowel replacements the short vowel into the long vowel. It is called the method of vowel lengthening. There are 20 words from the total 50 words in which the vowel is changing by the vowel lengthening. The researcher found that the change happened because the vowel is located before voiced consonants and Tagalog 


\section{Jurnal DinamikA}

Volume 2 No. 2 (2021)

E-ISSN: $2723-1410$

Website: https://jurnal.iainsalatiga.ac.id/index.php/dinamika/index

phonology's environment. Thus, the changing of those vowels comes to be the dominant cause of the vowel changes found in English words pronounced by Filipino speakers in the short movie's conversation.

\section{References}

Frijuniarsi, N. (2018). Error in Vowel Pronunciation Made by Informatics Students. Journal of English Language Teaching Vol. 2 , 149-159.

Fromkin, V., Rodman, R., \& Hyams, N. (2003). An Introduction to Language. New York: Michael Rosenberg.

Halle, M. (1962). Speech Recognition: A Model and A Program for Research. IEEE.

Hazen, K. (2014). An Introduction to Language. United Kingdom: John Wiley\&Sons.

Hermastuti, S. I., \& Isti'anah, A. (2018). Consonant Changes in Korean Singers' Pronunciation. Journal of Language and Literature Vol.18 No.1 , 28-35.

King, R. (1973). Rule Insertion. Linguistic Society of America 49 (3) , 551-578.

McMohan, A. (2002). An Introduction to English Phonology. Edinburgh: Edinburgh University Press Ltd.

Odden, D. (2005). Introducing Phonology. New York: Cambridge University Press.

Purba, D., Bangun, M., Pramana, E., Sinaga, R., \& Tarigan, S. (2019). An Analysis Students' Vowel Pronunciation. Linguistics English Education and Art Journal Vol. 3 No.1, 180-188.

Samarin, W. (1987). Sociolingustics; An International Handbook of the Science of Language and Society. In N. Ammon, Dittmar, \& K, Lingua Franca (pp. 371 374). Berlin \& New York: Walter de Gruyter.

Walker, R. (2011). Vowel Patterns in Language. New York: Cambridge University Press. 
Jurnal DinamikA

Volume 2 No. 2 (2021)

E-ISSN: $2723-1410$

Website: https://jurnal.iainsalatiga.ac.id/index.php/dinamika/index

Weisler, S., \& Milkekic, S. P. (2000). Theory of Language : A Bradford book. London: MIT Press.

Appendices

\begin{tabular}{|c|c|c|c|c|c|}
\hline No. & $\begin{array}{l}\text { English } \\
\text { word }\end{array}$ & $\begin{array}{l}\text { English } \\
\text { Pronunciation }\end{array}$ & $\begin{array}{l}\text { Tagalog } \\
\text { Pronunciation }\end{array}$ & $\begin{array}{l}\text { The } \\
\text { Vowel } \\
\text { Change }\end{array}$ & $\begin{array}{l}\text { Phonological } \\
\text { Process }\end{array}$ \\
\hline 1 & Hang & /hæy / & [ hay ] & $\begin{array}{l}/ \mathfrak{x} / \rightarrow \\
{[\mathrm{a}]}\end{array}$ & $\begin{array}{l}\text { Vowel } \\
\text { lengthening }\end{array}$ \\
\hline 2 & React & /riækt/ & [reakt] & $\begin{array}{l}/ \mathfrak{x} \rightarrow \mathbf{} \\
{[\mathrm{a}]}\end{array}$ & $\begin{array}{l}\text { Vowel } \\
\text { lengthening }\end{array}$ \\
\hline 3 & Graduation & /græd3ueIfn/ & [graduefon] & $\begin{array}{l}/ \mathrm{e} / \rightarrow \\
{[\mathrm{a}]} \\
\Theta \rightarrow[\mathrm{o}]\end{array}$ & $\begin{array}{l}\text { Vowel } \\
\text { lengthening } \\
\text { Vowel } \\
\text { Insertion of } \\
\text { /o/ }\end{array}$ \\
\hline 4 & Matter & /mætə(r)/ & [mater] & $\begin{array}{l}/ \mathfrak{x} / \rightarrow \\
{[\mathrm{a}]} \\
/ ə / \rightarrow[\mathrm{e}]\end{array}$ & $\begin{array}{l}\text { Vowel } \\
\text { lengthening } \\
\text { Vowel raising }\end{array}$ \\
\hline 5 & Passion & $/ \mathrm{p} \circledast \mathrm{n} /$ & [pafon] & $\begin{array}{l}/ \mathrm{x} / \rightarrow \\
\text { [a] } \\
\Theta \rightarrow[\mathrm{o}]\end{array}$ & $\begin{array}{l}\text { Vowel } \\
\text { lengthening } \\
\text { Vowel } \\
\text { insertion of } \\
\text { /o/ }\end{array}$ \\
\hline
\end{tabular}


Jurnal DinamikA

Volume 2 No. 2 (2021)

E-ISSN: $2723-1410$

Website: https://jurnal.iainsalatiga.ac.id/index.php/dinamika/index

\begin{tabular}{|c|c|c|c|c|c|}
\hline 6 & Actually & /æktfuəli/ & [aktuali] & $\begin{array}{l}/ x / \rightarrow \\
{[a]}\end{array}$ & $\begin{array}{l}\text { Vowel } \\
\text { lengthening }\end{array}$ \\
\hline 7 & Exam & /Igzæm/ & [igsim] & $/ \mathrm{I} / \rightarrow[\mathrm{i}]$ & $\begin{array}{l}\text { Vowel } \\
\text { lengthening }\end{array}$ \\
\hline 8 & Deserve & /dIz3rv/ & [diserv] & $\begin{array}{l}/ \mathrm{I} / \rightarrow[\mathrm{i}] \\
/ 3 / \rightarrow[\mathrm{e}]\end{array}$ & $\begin{array}{l}\text { Vowel } \\
\text { lengthening } \\
\text { Vowel raising }\end{array}$ \\
\hline 9 & Interested & /IntrəstId/ & [interestid] & $\begin{array}{l}/ \mathrm{I} / \rightarrow[\mathrm{i}] \\
\Theta \rightarrow[\mathrm{e}] \\
/ \partial / \rightarrow[\mathrm{e}]\end{array}$ & $\begin{array}{l}\text { Vowel } \\
\text { lengthening } \\
\text { Vowel } \\
\text { insertion of } \\
\text { /e/ } \\
\text { Vowel raising }\end{array}$ \\
\hline 10 & Possibility & /pDsəbIləti/ & [pasibiliti] & $\begin{array}{l}/ \mathrm{D} / \rightarrow[\mathrm{a}] \\
/ \mathrm{I} / \rightarrow[\mathrm{i}] \\
/ \partial / \rightarrow[\mathrm{i}]\end{array}$ & $\begin{array}{l}\text { Vowel } \\
\text { lengthening } \\
\text { Vowel raising }\end{array}$ \\
\hline 11 & Important & /ImpOrtnt/ & [importante] & $\begin{array}{l}/ \mathrm{I} / \rightarrow[\mathrm{i}] \\
/ \mathrm{J} / \rightarrow \\
{[\mathrm{o}]} \\
\Theta \rightarrow[\mathrm{a}]\end{array}$ & $\begin{array}{l}\text { Vowel } \\
\text { lengthening } \\
\text { Vowel } \\
\text { insertion of } \\
\text { /a/ }\end{array}$ \\
\hline
\end{tabular}


Jurnal DinamikA

Volume 2 No. 2 (2021)

E-ISSN: $2723-1410$

Website: https://jurnal.iainsalatiga.ac.id/index.php/dinamika/index

\begin{tabular}{|c|c|c|c|c|c|}
\hline & & & & $\Theta \rightarrow[\mathrm{e}]$ & $\begin{array}{l}\text { Vowel } \\
\text { insertion of } \\
\text { /e/ }\end{array}$ \\
\hline 12 & Release & /rrlis/ & [rilise] & $\begin{array}{l}/ \mathrm{I} / \rightarrow[\mathrm{i}] \\
\Theta \rightarrow[\mathrm{e}]\end{array}$ & $\begin{array}{l}\text { Vowel } \\
\text { lengthening } \\
\text { Vowel } \\
\text { insertion of } \\
\text { /e/ }\end{array}$ \\
\hline 13 & Board & /bord/ & [borde] & $\begin{array}{l}/ \mathrm{O} / \rightarrow \\
{[\mathrm{o}]} \\
\Theta \rightarrow \text { [e] }\end{array}$ & $\begin{array}{l}\text { Vowel } \\
\text { lengthening } \\
\text { Vowel } \\
\text { insertion of } \\
\text { /e/ }\end{array}$ \\
\hline 14 & Thought & $/ \theta \mathrm{ot} /$ & [totch] & $\begin{array}{l}/ \mathrm{J} / \rightarrow \\
{[\mathrm{o}]}\end{array}$ & $\begin{array}{l}\text { Vowel } \\
\text { lengthening }\end{array}$ \\
\hline 15 & Fast & /fast/ & [fast] & $\begin{array}{l}/ \mathrm{a} / \rightarrow \\
\text { [a] }\end{array}$ & $\begin{array}{l}\text { Vowel } \\
\text { lengthening }\end{array}$ \\
\hline 16 & Problem & /prabləm/ & [prablema] & $\begin{array}{l}/ \mathrm{a} / \rightarrow \\
\text { [a] } \\
/ \partial / \rightarrow \text { [e] } \\
\Theta \rightarrow[\mathrm{a}]\end{array}$ & $\begin{array}{l}\text { Vowel } \\
\text { lengthening } \\
\text { Vowel raising } \\
\text { Vowel } \\
\text { insertion of } \\
\text { /a/ }\end{array}$ \\
\hline
\end{tabular}


Jurnal DinamikA

Volume 2 No. 2 (2021)

E-ISSN: $2723-1410$

Website: https://jurnal.iainsalatiga.ac.id/index.php/dinamika/index

\begin{tabular}{|c|c|c|c|c|c|}
\hline 17 & Conscious & /kanfəs/ & [konsus] & $\begin{array}{l}/ \mathrm{a} / \rightarrow \\
{[\mathrm{o}]} \\
/ \partial / \rightarrow \\
{[\mathrm{u}]}\end{array}$ & $\begin{array}{l}\text { Vowel } \\
\text { lengthening } \\
\text { Vowel raising }\end{array}$ \\
\hline 18 & Out & / avt/ & [aut] & $\begin{array}{l}/ v / \rightarrow \\
{[u]}\end{array}$ & $\begin{array}{l}\text { Vowel } \\
\text { lengthening }\end{array}$ \\
\hline 19 & Cum & $/ \mathrm{kUm} /$ & [kum] & $\begin{array}{l}/ v / \rightarrow \\
{[u]}\end{array}$ & $\begin{array}{l}\text { Vowel } \\
\text { lengthening }\end{array}$ \\
\hline 20 & Sure & $/ \int u r /$ & [Jure] & $\begin{array}{l}/ \mathrm{v} / \rightarrow \\
{[\mathrm{u}]} \\
\Theta \rightarrow[\mathrm{e}]\end{array}$ & $\begin{array}{l}\text { Vowel } \\
\text { lengthening } \\
\text { Vowel } \\
\text { insertion of } \\
\text { /e/ }\end{array}$ \\
\hline 21 & Food & / fud/ & [fudi] & $\Theta \rightarrow[\mathrm{i}]$ & $\begin{array}{l}\text { Vowel } \\
\text { insertion of } \\
\text { /i/ }\end{array}$ \\
\hline 22 & Class & / klas/ & [ klase] & $\Theta \rightarrow[\mathrm{e}]$ & $\begin{array}{l}\text { Vowel } \\
\text { insertion of } \\
\text { /e/ }\end{array}$ \\
\hline
\end{tabular}

